\section{Reform urged for "hellish" Japanese education system}

Tokyo

JAPAN's National Council on Education Reform has handed over its third set of recommendations to Prime Minister Yasuhiro Nakasone. The council calls for a more open and flexible school system, the promotion of lifelong education, and more funds for the national universities. But there are no radical proposals to deal with the major problems besetting Japan's higher education system - the preuniversity examination "hell" and elitism in the universities - and the Ministry of Education's strict control over school textbooks will be maintained.

The council was set up by Nakasone in 1984 to map out the first major reforms of Japan's education system since the postwar US occupation. Two sets of recommendations have already been issued, in June 1985 and April 1986 (see Nature 318, $7 ; 1985$; and 319,$347 ; 1988)$. But from the outset the council has been torn by internal strife and several of the more sweeping reforms put forward by council members have been dropped or shelved for further discussion.

In its latest proposals, the council calls for increased public and private sector support for the universities (private and national), by establishing financial links with local governments, instituting tax incentives for donations by private individuals and organizations, and by encouraging national universities to establish their own foundations with such donations and to use effectively land they own for investment purposes. But the council stops short of an earlier proposal by one of the council's subcommittees to convert national universities into corporations - a decision on this will be made before the council dissolves in August.

A university tenure system is recommended, instead of life-time employment, with some staff being hired on a contract basis to increase fluidity in academic appointments. And qualifications criteria will be relaxed to allow employment of more non-academic and foreign staff.

A major thrust of the latest recommendatios is the promotion of lifelong education. The council calls on universities to open their doors to adult job-holders at both the undergraduate and graduate level, and local governments are recommended to establish "intelligent" adult education facilities to be open around the clock and contain advanced computers.

But there is little to be found in the recommendations to solve the intense competition at the high school level. Senior high schools are encouraged to consider achievement reports from junior high schools, interviews and composit- ions, and to place more emphasis on the ability to think and solve problems, instead of rote learning, in their entrance exams. But the system of after-hours cram schools will be maintained; the council merely recommends that the central and local governments supply parents with accurate information on this private education industry, which is expanding by leaps and bounds.

One enterprising cram school, Gakkyusha Co., plans to launch nationwide television lessons via a communications satellite to be launched by Japan Communications Satellite Co. next year. Others have started summer cram camps in winter ski resorts, squeezing students into every available space, including the ski-drying room, to prepare them for the highly competitive spring entrance examinations for junior and senior high schools.

Rigid control over what these school pupils read will be maintained by the Ministry of Education, Science and Culture. The council's first subcommittee on reform for education for the next century had called for abolition of the ministry's textbook screening system, which has been strongly criticized by neighbouring nations for toning down descriptions of Japan's militaristic past. But the subcommittee on primary and secondary education, which is close to the ministry, and a committee of the ruling Liberal
Democratic Party, including three former education ministers, opposed the move. The screening system will be simplified from a three-stage to one-stage process, but critics say this will merely increase the ministry's control over textbooks.

A minor change in the "hell" of university entrance examinations has already been instituted. This year candidates were allowed to sit entrance examinations for two or three national universities, instead of only one. This was done by dividing the universities into three groups according to area and holding the examinations for each group at different times.

In the past, national university entrance examinations were all held on the same day, each university having its own examination on its own campus. Japan's young university aspirants leapt at the new chance, commuting back and forth on the bullet train, textbooks in hand, in this their first opportunity to sit examinations for both of Japan's most prestigious universities, Kyoto and Tokyo.

The result was a dilemma for the universities. How many applicants should they accept to fill their quota? Kyoto's famed science faculty undershot the mark, accepting 485 applicants for 291 places. Hours before the application deadline on 25 March only 220 had accepted, the rest presumably having chosen Tokyo, and telegrams were hurriedly sent out to additional applicants to fill the quota. But although Kyoto University's pride may have been dented, there is no indication that the competition for entrance to Japan's most elite universities has subsided.

David Swinbanks

\title{
Falsified data help to keep Soviet metal pockets lined
}

\section{London}

Several Soviet metallurgical plants have been accused of falsifying metallurgical data on a new tungsten-free steel to safeguard their own pockets. The accusation, made during a broadcast of Moscow television's popular Science and Life programme last month, is that the new steel has been falsely represented as unsatisfactory to keep it off the market.

Under the traditional system of financial rewards in the Soviet Union bonuses and other incentive payments are determined by gross turnover. The search for tungsten-free steels was begun some years ago but, according to Moscow television, the new steels would have been so much cheaper than those using tungsten that the turnover of the machine-tool fabrication plants using them would have lost money, on paper at least.

Institutes of Azerbaijan Academy of Sciences appear to have played an important part in the development of the tung- sten-free steels, partly through a special design bureau known as Kristall. N. M. Suleiman, director of the Kristall bureau, told television journalist B. V. Goldaev that there had been opposition to the new steels in the industry and that, on some occasions, the results of laboratory tests had been falsified. But, he said, tests carried out by industrial enterprises, especially the KamAZ enterprise, had shown that tools made from the new steel performed well. Even so, Suleimain said, the Soviet Ministry of the Machine Tool and Toolmaking had ignored the new steel.

M. A. Stremel, a technologist, pointed directly to the economic paradox that, whatever the merits of the new steels, "no metallurgical works is going to ruin itself" by producing them at a third of the price of conventional tungsten steel. A reform now at the draft stage would link performance to net rather than gross turnover of enterprises, but is not expected to be in force generally before $1990 . \quad$ Vera Rich 